ISSN 1392-3196 / e-ISSN 2335-8947

Zemdirbyste-Agriculture, vol. 102, No. 2 (2015), p. 343-350

DOI 10.13080/z-a.2015.102.044

\title{
The occurrence of Alternaria species on cabbage in Iran
}

\author{
Tahere RAHIMLOO, Youbert GHOSTA \\ University of Urmia \\ Urmia, Iran \\ E-mail: ghoosta@gmail.com
}

\begin{abstract}
In a study on Alternaria species, associated with cabbage black spot disease in Urmia, West Azerbaijan, Iran, cabbage fields were inspected during the growing seasons of 2012-2013 and leaves with suspected symptoms of Alternaria infection were collected. A total of 135 isolates with Alternaria characteristics were obtained from 10 main growing areas in this region and studied taxonomically. On the basis of morphological characteristics of the studied isolates, 8 species viz. Alternaria arbusti, A. brassicicola, A. destruens, A. infectoria, A. perangusta, A. tenuissima, A. turkisafria and A. vaccinii were identified. Alternaria tenuissima with 53 isolates, $A$. brassicicola with 38 isolates and $A$. destruens with 29 isolates had respectively the highest frequency among the identified species and distributed all over the studied area. A. arbusti and A. perangusta each with only one isolate had the lowest frequency. Results obtained from the pathogenicity tests showed that all the tested isolates from identified species were pathogenic on cabbage leaves, although there were statistically significant differences in virulence of the tested isolates. A. brassicicola isolates had the highest virulence and A. arbusti and $A$. vaccinii isolates had the lowest virulence. Isolates belonging to other species had moderate virulence. Except $A$. brassicicola which had been previously reported from cabbage in Iran, all other seven species are reported for the first time from cabbage as the causal agents of black spot disease. Also, A. arbusti, A. perangusta and A. vaccinii are reported as new species for Iran mycoflora.
\end{abstract}

Key words: Alternaria blight, Black leaf spot, Brassica oleracea, pathogen, taxonomy, virulence.

\section{Introduction}

White headed cabbage (Brassica oleraceae L. var. capitata L. f. alba DC) is a biennial herb in the Brassicaceae family which is commonly grown in temperate regions. The cultivation history of cabbage goes back to 600 B.C. Several insect pests and plant pathogens attack this plant worldwide, and where pest management programs were not implemented appropriately, severe losses could occur both in the field and in the store. One of the most common and important plant pathogens which causes qualitative and quantitative losses and reduces plant shelf-life is cabbage black spot disease which is caused by Alternaria species. It is reported that the yield loss caused by Alternaria blight disease on oilseed Brassicas is up to $60 \%$ (Kolte, 2002). A complex of three Alternaria species viz. A. brassicicola, A. brassicae and $A$. japonica has been reported as the causal agents of black spot disease of crucifers (Peruch et al., 2006; Reis, Boiteux, 2010). During the study aimed to identify causal agents of dark leaf spot disease of the four brassica crops grown in Thailand, A. brassicicola was the only identified species based on morphological and molecular characteristics (Pattanamahakul, Strange, 1999). In a survey of species causing Alternaria leaf spots on Brassica species in Pernambuco, A. brassicae was found in all Chinese cabbage fields, while $A$. brassicicola was found in all fields of cabbage, cauliflower and broccoli, an indication of host preferences (Michereff et al., 2012). In a recent study to determine pathogen species diversity on oilseed Brassicas, Alternaria brassicae, A. brassicicola and A. alternata were isolated from infected samples and $A$. brassicae was the dominant species (Aneja et al., 2014). The genus Alternaria is a cosmopolitan fungus with worldwide distribution that includes saprobic, endophytic and animal/plant pathogenic species (Grisan et al., 2011; Polizzotto et al., 2012). Many species of Alternaria are known as important plant pathogens causing plant diseases and postharvest rots on a wide range of crops (Woudenberg et al., 2013). Some taxa are gaining prominence as emerging human pathogens particularly in immunocompromised patients or as airborne allergens (Hoog de et al., 2000; Thomma, 2003; Simmons, 2007). Host range is varied and the genus ranks $10^{\text {th }}$ among nearly 2,000 fungal genera in the USDA Fungal Host Index based on total number of recorded hosts (Farr et al., 1989). Also, the taxonomy of Alternaria has changed dramatically during the recent years (Simmons, 2007; Lawrence et al., 2013; 2014; Woudenberg et al., 2013). Because of the significant negative effects of Alternaria species on vegetation and humans, a correct identification of Alternaria species would be of great value in order to understand their biology and ultimately to best control them. In Iran, Alternaria brassicae was reported for the first time from cabbage (Ershad, 2009). At present, three species were reported from cabbages in Iran. A. brassicae was reported from Ardabil, Moghan, Urmia and Tabriz (Ghosta et al., 2003; Ershad, 2009); 
A. brassicicola was reported from Ardabil, Qom, Karaj, Lahijan, Urmia, Tabriz, Sarab and Tooiserkan (Ghosta, 2004; Ershad, 2009), and A. japonica was reported from Urmia (Ghosta et al., 2003). In spite of widespread occurrence of cabbage black leaf spot disease and its economic losses, there is not any specific study on the disease, species composition of the causal agents and the pathogenicity of different species in Urmia or other main cabbage growing areas of Iran.

The objective of the present study is to isolate, identify and characterize the pathogenicity of different Alternaria species from cabbage in Urmia, West Azerbaijan, one of the main cabbage growing areas in northwest part of Iran.

\section{Material and methods}

Isolation and purification of fungal isolates. During the growing seasons (summer and autumn) of 2012-2013, cabbage fields in Urmia, West Azerbaijan, Iran were inspected and plants with suspected symptoms of Alternaria infection were collected. Infected leaves were placed separately in paper bags, transported to the laboratory and incubated at $4^{\circ} \mathrm{C}$. Isolation of the fungi was done immediately. Leaves were washed thoroughly under tap water, and then surface sterilized with 0.5 percent sodium hypochlorite solution for $5 \mathrm{~min}$, rinsed again with sterile distilled water and blotted dry on sterile paper towels. Leaves were cut into small pieces and plated on potato dextrose agar (PDA). Some of the leaf samples were placed in Petri plates containing a moistened sterile filter paper. Petri plates were incubated in the dark at $23-25^{\circ} \mathrm{C}$ and the fungi growing up from the margins or surfaces of the plant samples were transferred into new PDA plates. In the cases that fungal conidiophores and conidia were formed on the collected plant samples, the conidia with Alternaria characteristics were taken directly by fine sterile needle and plated on PDA. Purification of the isolated fungi was done by transferring single spores or hyphal tips onto fresh PDA plates. Purified fungi were grown in potato carrot agar (PCA) slants containing a piece of filter paper and after adequate growth, the slants were incubated at $4^{\circ} \mathrm{C}$ for further studies.

Species identification. For species identification, the method of Simmons (2007) was followed. The purified isolates were cultured on PCA medium and incubated at $23-25^{\circ} \mathrm{C}$ for $5-7$ days under a cool white fluorescent light/dark cycle of $8: 16 \mathrm{~h}$ and without humidity control. After this period, the sporulation pattern of the isolates was examined by direct observation of intact conidia by means of binocular dissecting microscope at about $64^{\times}$magnification. Arrangement of conidia on conidiophores, number of conidia in chains and patterns of chain branching were examined without disrupting the colony. For examination of microscopic details, mounts were prepared in pure lactic acid without added dye. Preparations were heated gently and microscopic details such as septation, colour, size, presence or absence of secondary conidiophores and its length and wall ornamentation was recorded from observations made at $400^{\times}$and $1000^{\times}$magnifications. Dimensions are based on observing 50 conidia per isolate.

Pathogenicity tests. In order to determine the pathogenicity of the isolates, inoculation method using agar blocks containing mycelia and spores were used on detached cabbage leaves cv. 'Koikaze'. For this, the isolates were grown on PCA culture medium at $25^{\circ} \mathrm{C}$, $8: 16 \mathrm{~h}$ light/dark cycle for 7 days. Healthy, two months' old cabbage leaves were used in pathogenicity tests. Leaves were first washed thoroughly under tap water, and then were surface sterilized with 0.5 percent sodium hypochlorite solution. In the inoculation sites, a small lesion was made with sterile needle and an agar plugs (diameter $5 \mathrm{~mm}^{2}$ ) were placed on the lesion mycelial side down. In controls, agar plugs without fungal mycelia were used. Inoculated leaves were placed in plastic containers containing wet, three layers sterilized filter paper. The containers were incubated at $20-22^{\circ} \mathrm{C}$ for 14 days. Each experiment included three replicates per treatment. All experiments were repeated twice. Isolations were made from all inoculated leaves and the isolates were identified as described initially to fulfil Koch's postulates. Lesion diameters around the inoculated sites were measured and used in comparisons. Results were analyzed using SPSS software program and means were compared using Tukey's test.

\section{Results and discussion}

Fungal isolates. Cabbage leaves with dark spots were found in all visited fields in the studied area. Isolates with Alternaria characteristics were dominant among the isolated fungi, although some isolates with Stemphylium, Cladosporium and Penicillium characteristics were also found among the isolated fungi. Overall, 135 isolates with Alternaria characteristics were obtained from different locations (Table 1).

Species identification. Species identifications were done based on morphological characteristics. Eight species viz. Alternaria arbusti, A. brassicicola, A. destruens, A. infectoria, A perangusta, A. turkisafria, A. tenuissima and $A$. vaccinii were identified. Among the identified species, $A$. tenuissima, A. brassicicola and $A$. destruens with 53, 38 and 29 isolates had respectively the highest frequency and distribution, and $A$. arbusti and $A$. perangusta each with one isolate, had the lowest frequency. Except $A$. brassicicola which had been previously reported from cabbage in Iran, all the other seven species are reported for the first time from cabbage and cabbage is as matrix nova for these species. Also, $A$. arbusti, $A$. perangusta and $A$. vaccinii are reported as new species to Iran mycoflora. Identified species are described briefly alphabetically.

1. Alternaria arbusti (Simmons, 1993). Mean colony diameter of the studied isolate on PCA medium at $23-25^{\circ} \mathrm{C}$ after 7 days is $40 \mathrm{~mm}$. Colony colour is grey. Aerial hyphae are low. Primary conidiophores are erect and simple, mostly with one conidiogenous locus, rarely 2-4. Conidia ovoid to long ellipsoid, produced in short chains and have relatively long secondary conidiophores. Transverse septa are thick and darker brown than the outer conidial wall. Conidia have 3-6(-8) transverse and 1-2 longitudinal septum in the wider part, $25-45 \times 8-16 \mu \mathrm{m}$ (Fig. 1). This species was reported previously from leaf spots of Pyrus pyrifolia and cherry fruit cv. 'Rainier' (Simmons, 1993). One isolate was obtained from cv. 'Emamzadeh' in this study. This is the first report of the presence of $A$. arbusti in Iran and cabbage is as new host for this species. 
Table 1. Identified Alternaria species, isolates and their frequencies

\begin{tabular}{|c|c|c|}
\hline Species & Isolate & Species frequencies \\
\hline A. arbusti & EM6 & $0.74 \%$ \\
\hline A. brassicicola & $\begin{array}{l}\text { VZ3, EM1, EM2, EM4, LR2, LR10, KA8, HA11, HA12, HA13, HA14, HA15, QA13, } \\
\text { QA14, QA15, QA16, QA17, QA18, QA19, QA20, QA21, QA24, QA25, QA27, QA30, } \\
\text { QA31, UF3, UF5, TP1, TP2, TP3, TP4, TP5, TP6, TP11, TP15, TP16, TP17 }\end{array}$ & $28.14 \%$ \\
\hline A. destruens & $\begin{array}{l}\text { EM9, EM11, EM12, EM23, LR3, LR9, LR13, LR14, LR15, LR16, LR17, KA4, KA5, } \\
\text { KA10, HA10, QA3, QA4, QA6, QA7, QA8, QA23, TP7, TP14, NA2, GO2, GO5, GT1, } \\
\text { GT3, GT4 }\end{array}$ & $21.48 \%$ \\
\hline A. infectoria & EM10, UF1, UF2, LR19, HA6, QA9, QA11 & $5.18 \%$ \\
\hline A. perangusta & LR8 & $0.74 \%$ \\
\hline A. tenuissima & $\begin{array}{l}\text { VZ2, EM8, LR4, LR5, LR6, LR7, LR11, LR18, KA1, KA3, KA6, KA7, KA11, HA3, HA5, } \\
\text { HA7, HA17, HA18, HA19, HA20, HA23, QA1, QA2, QA3, QA5, QA10, QA12, QA22, } \\
\text { QA32, QA33, QA34, QA35, QA36, UF7, UF8, TP8, TP9, TP10, TP11, TP12, TP13, TP18, } \\
\text { GO3, GO4, GO6, GO7, PC, PC1, PC2, PC3, NA2, NA3, NA4 }\end{array}$ & $39.25 \%$ \\
\hline A. turkisafria & VZ1, HA2, HA13 & $2.22 \%$ \\
\hline A. vaccinii & EM7, HA4, UF4 & $2.22 \%$ \\
\hline
\end{tabular}

EM - Emamzadeh', VZ - 'Vazirabad', LR - 'Lake Road', KA - 'Kavsi', HA - 'Hosseinabad', QA - 'Qasemieh', UF - 'University Farms', TP - ‘Toprag gale', NA - 'Nazloo', GO - 'Gotello', GT - ‘Gog Tapeh', PC - 'Parchineh'
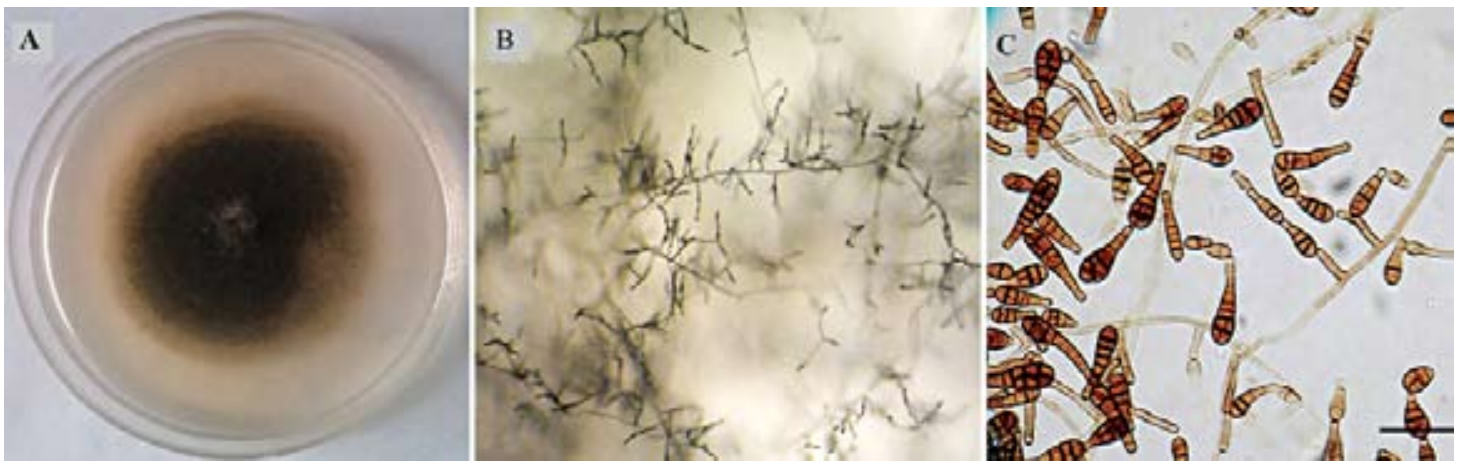

Figure 1. Alternaria arbusti: colony on potato carrot agar (PCA) after 7 days (A), sporulation pattern (B) and conidial chains and conidiophores $(\mathrm{C})($ scale bar $=50 \mu \mathrm{m})$. (For colour figures, please visit http://www.zemdirbyste-agriculture. 1t/1023_str44/)

2. Alternaria brassicicola (Schw.) (Wiltshire, 1947). Mean colony diameter of different isolates on PCA medium at $23-25^{\circ} \mathrm{C}$ after 7 days is $55 \mathrm{~mm}$. Colony colour is olivaceous to dark brown. Primary conidiophores arise directly from agar surface, mostly simple, with a single conidiogenous site, up to $125 \mu \mathrm{m}$ length. Conidia are borne on long branched chains; initial conidia large, ellipsoid to ovoid, 30-45 $\times 10-12 \mu \mathrm{m}$; younger conidia in a chain are smaller, ovoid, $12-25 \times 6-8 \mu \mathrm{m}$. Conidia have 5-7 transverse septa, usually without longitudinal septum, rarely with 1-2 longitudinal/oblique septa at the wider part. Transverse septa are thick and darker brown than the outer conidial wall (Fig. 2). This species had been previously reported in Iran and other parts of the world from cabbage and other taxa of Cruciferae, Digitalis purpurea, Phaseolus coccineus, Thymus vulgaris, Artemisia sp. and plant species in the genera of Linum, Papaver, Scrozonera and Phaseolus (Simmons, 2007; Ershad, 2009). 38 isolates were obtained in this study from all visited areas.
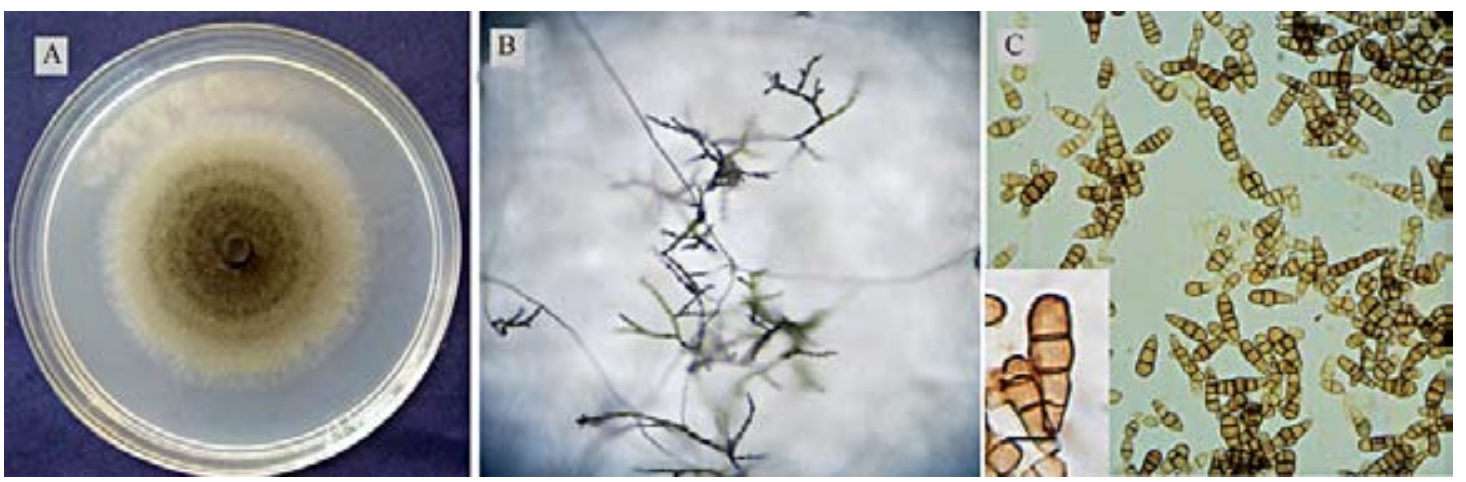

Figure 2. Alternaria brassicicola: colony on potato carrot agar (PCA) after 7 days (A), sporulation pattern (B) and conidia $(\mathrm{C})($ scale bar $=50 \mu \mathrm{m})$ 
3. Alternaria destruens (Simmons, 1998). Mean colony diameter of different isolates on PCA medium at $23-25^{\circ} \mathrm{C}$ after 7 days is $57 \mathrm{~mm}$. Colony colour is brown. Conidia are produced on short unbranched chains (4-8 conidia), rarely a short conidial branch with 1-2 conidia arises from a body cell of catenate conidium. Most conidia in chains appear beakless, but a few have a relatively long secondary conidiophore up to $60 \mu \mathrm{m}$. These prominent secondary conidiophores inserted in short, simple chains of conidia are diagnostic character of this species among the small-spored Alternaria. Conidia ovoid to ellipsoid, dark brown, 20-40 $\times 8-12 \mu \mathrm{m}$, with 3-5 transverse septa and rarely one longitudinal septum in the widest part (Fig. 3). This species was reported for the first time from Cuscuta gronovii Wild (Simmons, 1998) and from sunflower, eggplants, barley and mango in Iran (Ershad, 2009). 29 isolates were obtained from cabbage in this study in all visited areas and cabbage is a new host for this species.
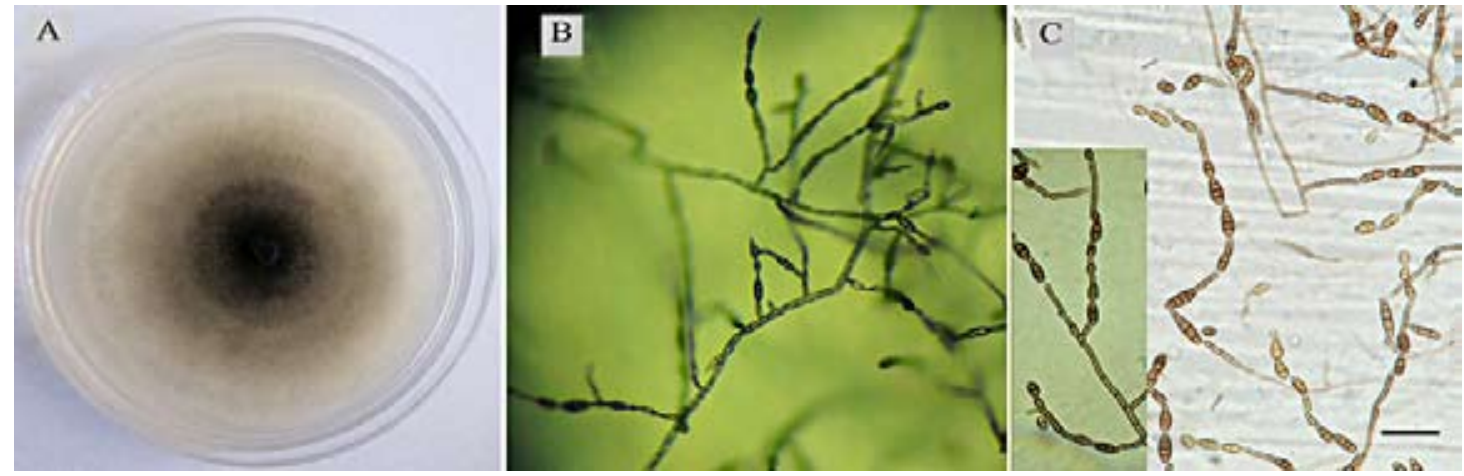

Figure 3. Alternaria destruens: colony on potato carrot agar (PCA) after 7 days (A), sporulation pattern (B) and conidial chains, primary and secondary conidiophores, long conidiophores between conidia (arrowheads, C) (scale bar $=50 \mu \mathrm{m})$

4. Alternaria infectoria (Simmons, 1986). Mean colony diameter of different isolates on PCA medium at $23-25^{\circ} \mathrm{C}$ after 7 days is $66 \mathrm{~mm}$. Primary conidiophores which arise from aerial hyphae or arise directly from agar surface are simple and have several geniculations. Conidia are produced on short branched chains (4-10 conidia). Primary conidia usually are the largest conidia. Conidia are ellipsoid to long ovoid, $30-45 \times 8-15 \mu \mathrm{m}$, with 3-6 transverse septa and $0-2(-3)$ longitudinal septa. Apical cell of primary conidia usually generate secondary conidiophores with variable length and several geniculations with branching chains of secondary conidia (Fig. 4). This species had been previously reported from sunflower, barley, apple, soybean, canola, kidney bean and wheat in Iran (Ershad, 2009). In this study, 7 isolates were obtained from cabbage in cvs. 'Emamzadeh', 'Qasemieh', 'Lake Road', 'Hosseinabad', 'Vazirabad' and 'Nazloo'. Cabbage is reported as a new host for this species.
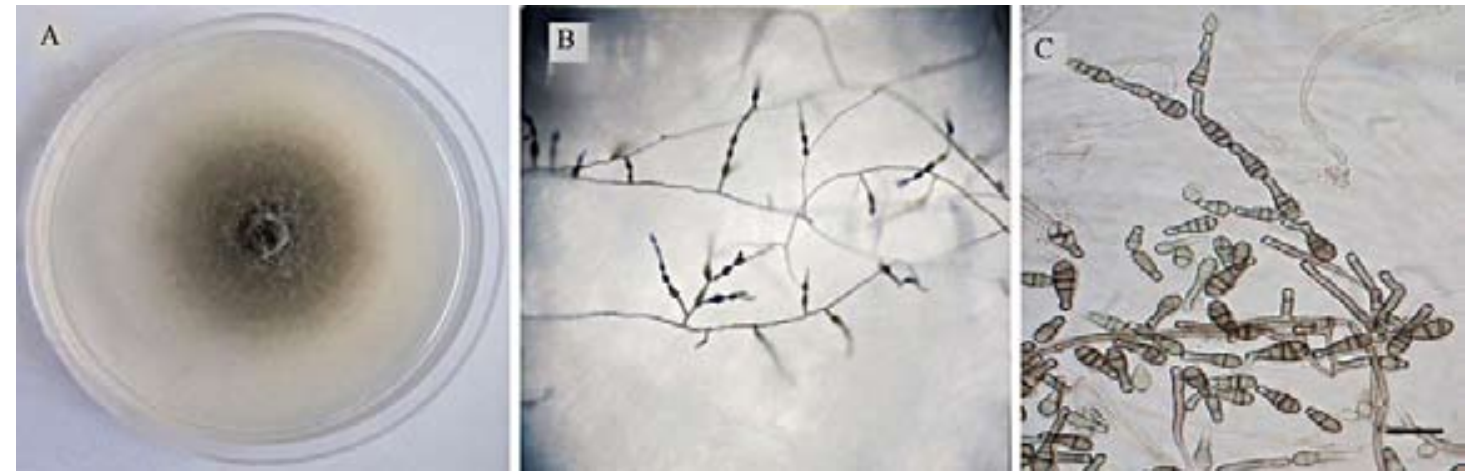

Figure 4. Alternaria infectoria: colony on potato carrot agar (PCA) after 7 days (A), sporulation pattern (B) and conidial chains and secondary conidiophores (arrowhead, C) (scale bar $=50 \mu \mathrm{m})$

5. Alternaria perangusta (Simmons, 1999). Mean colony diameter of the studied isolate on PCA medium at $23-25^{\circ} \mathrm{C}$ after 7 days is $64 \mathrm{~mm}$. Colony colour is brown. Primary conidiophores are short; conidia are produced in simple, long chains (10-18 conidia); conidia are long-narrow-ellipsoid, dilute yellow-tan; outer walls punctuate, with 3-5 transverse septa and without longitudinal septa, rarely with 1 longitudinal septum, $17-40 \times 6-8 \mu \mathrm{m}$. Younger conidia in chains are small, ovoid and with only one transverse septum (Fig. 5). One isolate from cv. 'Lake Road' was obtained in this study.
This species was reported originally from Citrus paradisi Macfad. $\times$ C. reticulata Blanco cv. 'Minneola' (Rutaceae) (Simmons, 2007) and is reported for the first time from cabbage. Also this species is new to Iran mycoflora.

6. Alternaria tenuissima (Kunze) (Wiltshire, 1933). Mean colony diameter of different isolates on PCA medium at $23-25^{\circ} \mathrm{C}$ after 7 days is $62 \mathrm{~mm}$. Colony colour is brown. Primary conidiophores arise directly from agar surface, up to $70 \mu \mathrm{m}$ length and have 1-3 geniculations. Conidia are produced in simple, short chains (4-8 conidia), are ovoid to obclavate, 20-45 $\times$ 

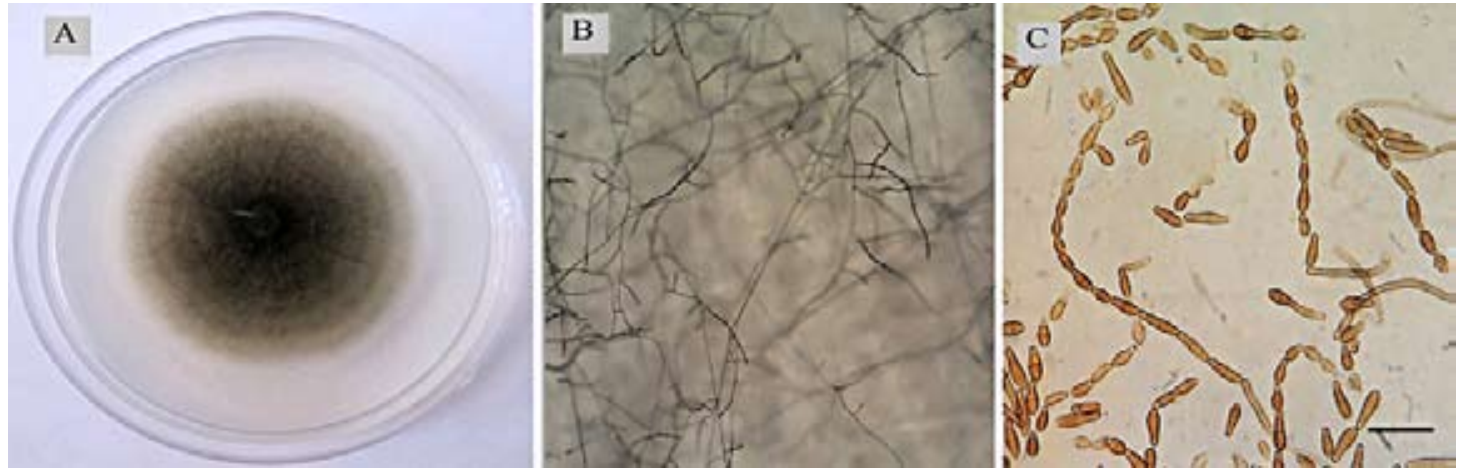

Figure 5. Alternaria perangusta: colony on potato carrot agar (PCA) after 7 days (A), sporulation pattern (B) and long conidial chains and narrow conidia $(\mathrm{C})($ scale bar $=50 \mu \mathrm{m})$

8-12 $\mu \mathrm{m}$. Conidia have $3-5$ transverse septa and $1-2$ longitudinal septa in the wider part (Fig. 6). This species was reported from different hosts and environments (Simmons, 2007; Ershad, 2009), but for the first time is

reported from cabbage in Iran. 53 isolates were obtained in this study from all the visited locations and it had the highest frequency among the identified species.
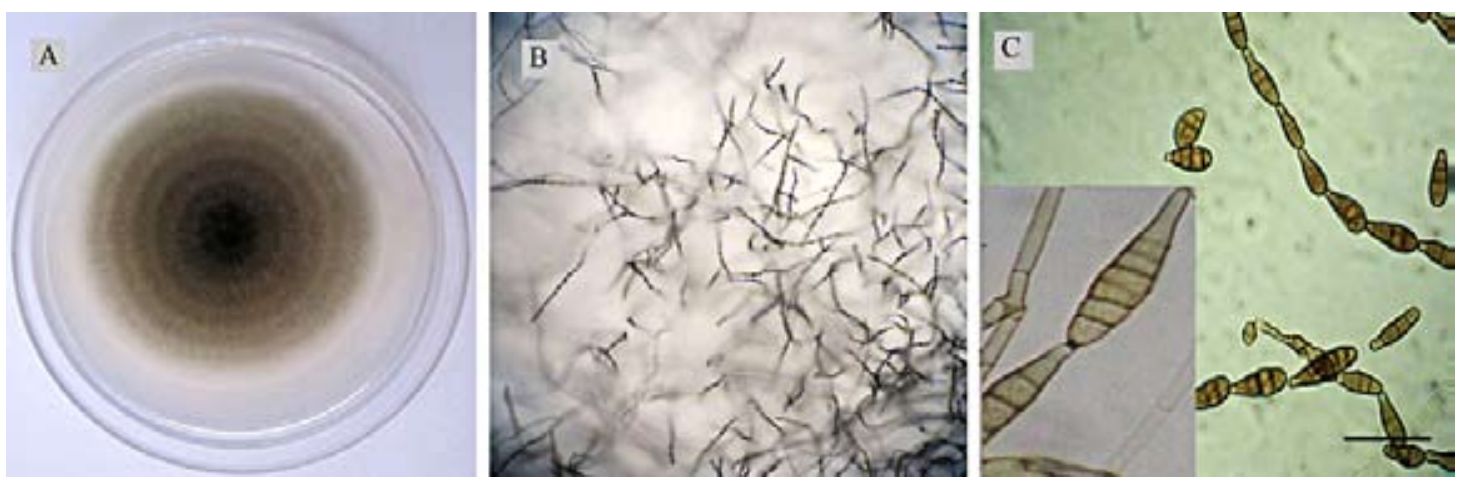

Figure 6. Alternaria tenuissima: colony on potato carrot agar (PCA) after 7 days (A), sporulation pattern (B) and conidial chains and conidia $(\mathrm{C})($ scale $\mathrm{bar}=50 \mu \mathrm{m})$

7. Alternaria turkisafria (Simmons, 1999). Mean colony diameter of different isolates on PCA medium at $23-25^{\circ} \mathrm{C}$ after 7 days is $55 \mathrm{~mm}$. Colony colour is brown. Primary conidiophores are short and arise directly from agar surface, up to $65 \mu \mathrm{m}$ length. Conidia are borne in long simple chains $(10-20$ conidia). First formed conidia are long-ellipsoid and younger conidia are long- ovoid. Conidia are medium yellow brown, with $3-5(-8)$ transverse septa and one longitudinal septum at the widest part, $15-50(-63) \times 8-10 \mu \mathrm{m}$ (Fig. 7). Three isolates were obtained in this study from cvs. 'Hosseinabad' and 'Vazirabad'. This species was reported from citrus plants in Turkey, South Africa and Iran (Simmons, 1999; Ghosta, 2004) and is reported for the first time from cabbage.
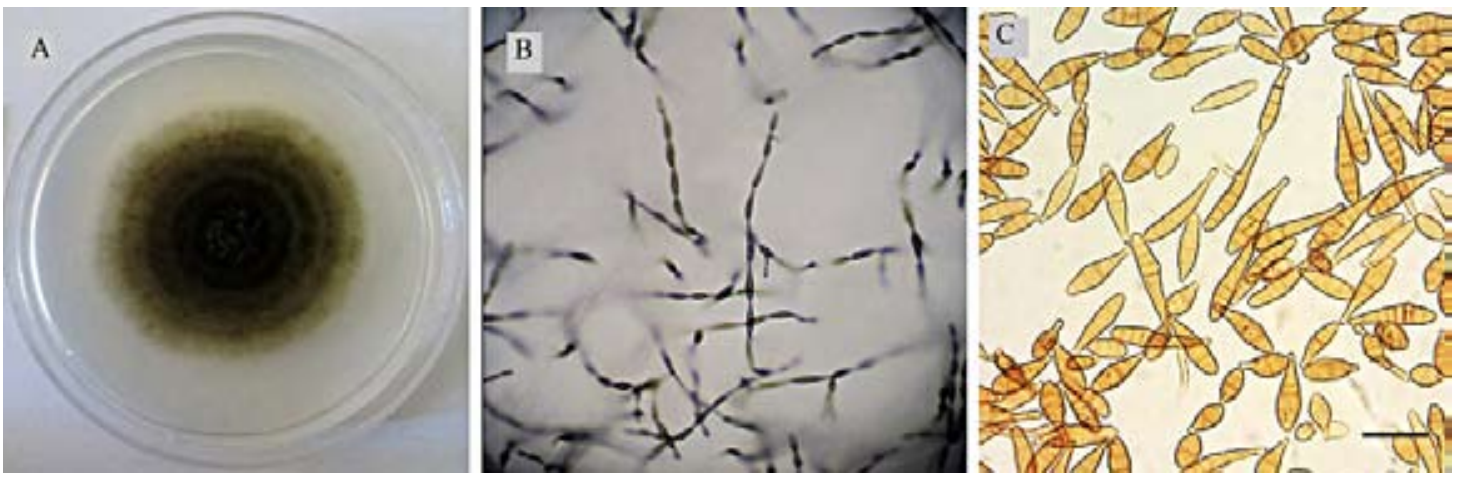

Figure 7. Alternaria turkisafria: colony on potato carrot agar (PCA) after 7 days (A), sporulation pattern (B) and conidia $(\mathrm{C})($ scale bar $=50 \mu \mathrm{m})$

8. Alternaria vaccinii (Simmons, 2007). Mean colony diameter of different isolates on PCA medium at $23-25^{\circ} \mathrm{C}$ after 7 days is $55 \mathrm{~mm}$. Colony colour is light gray. Primary conidiophores arise directly from agar surface, up to $125 \mu \mathrm{m}$ length. Conidia are produced in moderately long, simple or branched chains $(8-10$ conidia); secondary conidiophores short or more commonly long (up to $150 \mu \mathrm{m}$ ). Conidia are ovoid or subellipsoid, dilute brown, $13-35 \times 8-12 \mu \mathrm{m}$, with 2-6 transverse septa and usually no longitudinal septa or rarely with one longitudinal septum at the widest part (Fig. 8). This species was originally reported from 

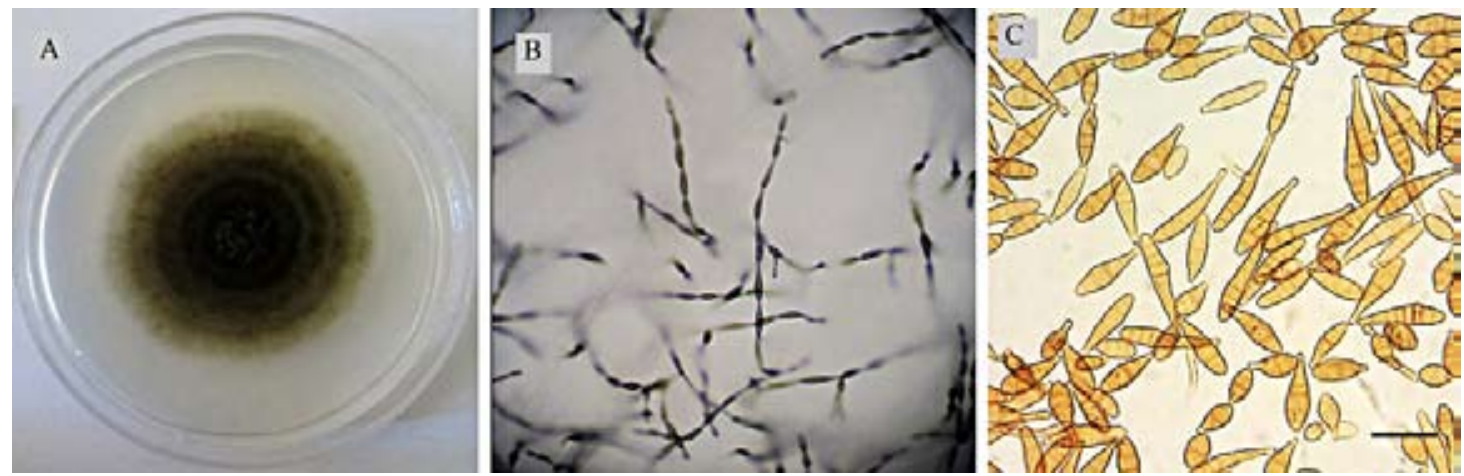

Figure 8. Alternaria vaccinii: colony on potato carrot agar (PCA) after 7 days (A), sporulation pattern (B) and conidia and long secondary conidiophores (arrowheads, C) $($ scale bar $=50 \mu \mathrm{m})$

Vaccinium sp. (Simmons, 2007). Three isolates in this study were obtained from cvs. 'Emamzadeh', 'Kavsi' and 'Vazirabad'. This is the first report of the occurrence of $A$. vaccinii from cabbage and is reported for the first time for Iran mycoflora.

Pathogenicity tests. Disease symptoms were seen as chlorosis and necrosis of leaf tissues around the inoculated sites after 14 days. No symptoms were seen in controls (Fig. 9).

On the basis of lesion dimensions, infected area was calculated based on ellipsoid formula. Comparison of data means showed that, although all the isolates were pathogenic on cabbage leaves, there were statistically significant differences among the virulence of the tested isolates from different species (Table 2).

Isolates belonging to $A$. brassicicola had the highest and $A$. arbusti and $A$. vaccinii isolates had the lowest virulence. Isolates belonging to the other species had moderate virulence (Fig. 10).

Until now, pathogenicity of $A$. brassicicola, $A$. brassicae and A. japonica are reported on cabbage plants from different locations and in this study; the pathogenicity of 7 other Alternaria species was confirmed. Species composition associated with black spot disease in different studies is somewhat different. In most studies on the identification of Alternaria species from brassicaceous hosts, A. brassicae, A . brassicicola and A. japonica were reported (Rop et al., 2009; Kumar et al., 2014), although in more recent study, A. alternata was also reported as the causal agent of the disease (Aneja et al., 2014). In a study on Alternaria species infecting brassicaceae in the Brazilian neotropics, A. brassicicola was prevalent

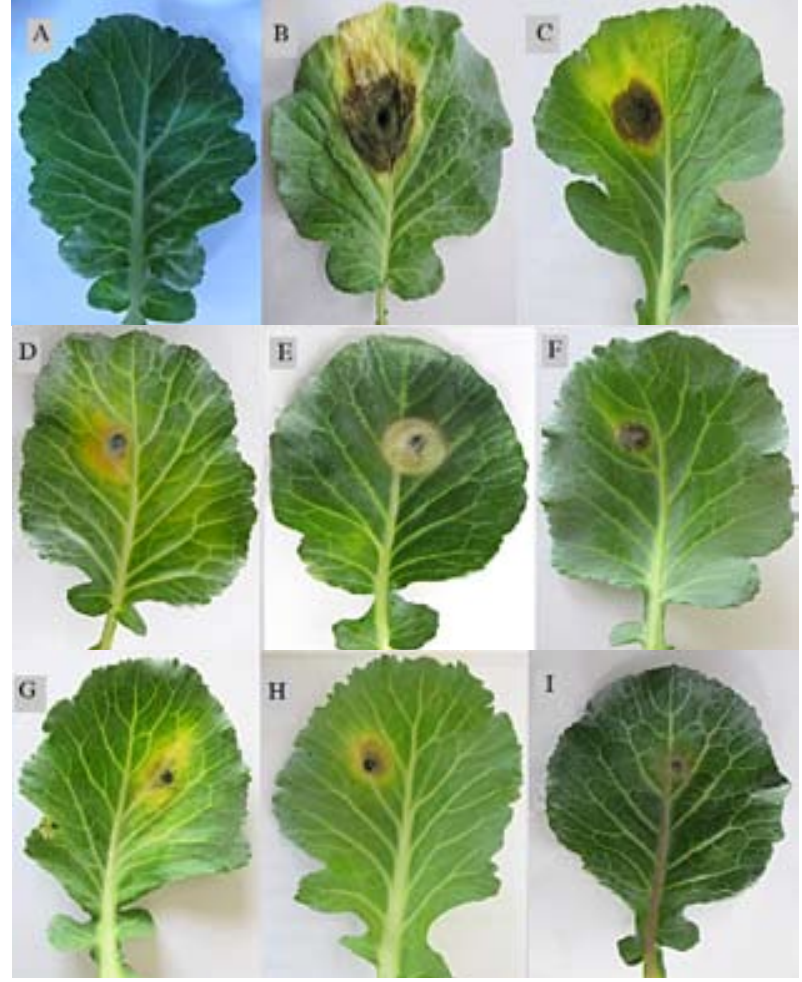

Figure 9. Pathogenicity tests of different species of Alternaria on detached cabbage leaves cv. 'Koikaze' under laboratory conditions: control (A), A. brassicicola (B), A. destruens (C), A. infectoria (D), A. turkisafria (E), A. tenuissima $(\mathrm{F})$, A. perangusta $(\mathrm{G})$, A. vaccinii $(\mathrm{H})$ and A. arbusti (I)

Table 2. ANOVA analysis of pathogenicity of various species of Alternaria on cabbage cv. 'Koikaze' leaves

\begin{tabular}{cccccc}
\hline Source & DF & Sum of squares & Mean squares & $F$ & $P$ \\
\hline Treatment & 7 & 2313.841 & 330.549 & 1910.687 & 0.000 \\
Error & 16 & 2.769 & 0.173 & & \\
Total & 23 & 2316.610 & & & \\
\hline
\end{tabular}

$\mathrm{DF}$ - degrees of freedom, $F$ - the test statistic, $P$ - the probability of a value of $F$ greater than or equal to the observed value

on Brassica oleracea complex, whereas A. brassicae was prevalent on Brassica rapa complex and weed species (Reis, Boiteux, 2010). In a study to determine Alternaria species causing black spot disease on cabbage and kale in Kenya, A. brassicicola and A. japonica were identified as the causal agents. $A$. brassicicola was predominant in cabbage and $A$. japonica was predominant in kale fields (Rop et al., 2009). In a study on black spot disease of canola in Iran, 5 different species of Alternaria were isolated and identified from diseased plants and A. brassicicola and A. japonica had the highest virulence. Also $A$. japonica was the dominant species (Nourani et al., 2008). In the revised studies on Alternaria species infecting Solanaceae, Caryophyllaceae and several other 


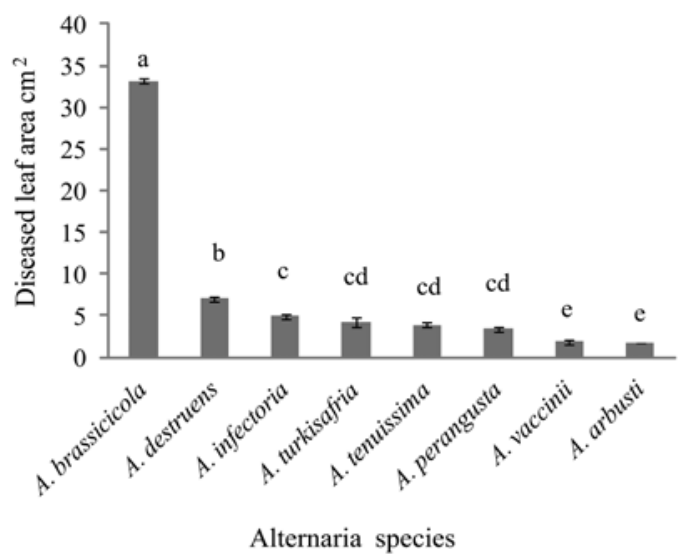

Figure 10. Diseased leaf area of cabbage cv. 'Koikaze' leaves, 14 days after inoculation with different species of Alternaria

host families, a lot of new species of Alternaria were identified and described (Simmons, 2000; 2007). Based on the revised species concept in the genus Alternaria and controversies in the past for identification of species in this large and complex genus, it is necessary to do more work on the identification of species composition in complex diseases. The results of this study showed that there are several species of Alternaria pathogenic on cabbage in the studied area, so more studies need to be done to determine Alternaria species diversity associated with cabbage black leaf spot disease in other cabbage growing regions. Due to the differences in pathogenicity of different species of Alternaria isolated from cabbage, it may be noted in studies related to breeding resistant varieties and other control strategies against black spot disease.

\section{Conclusions}

1. Eight species of Alternaria were identified from cabbage black spot disease in the studied area and their pathogenicity was confirmed based on Koch's postulates.

2. A. tenuissima, A. brassicicola and $A$. dstruens are dominant species of Alternaria on cabbage plants in Urmia, West Azerbaijan.

3. A. brassicicola isolates are identified as highly virulent and $A$. arbusti and $A$. vaccinii isolates as weakly virulent on cabbage plants.

4. Cabbage is reported as matrix nova for 7 Alternaria species, viz. A. arbusti, A. destruens, A. infectoria, A. perangusta, A. tenuissima, A. turkisafria and $A$. vaccinii.

5. Three species of Alternaria: A. arbusti, A. perangusta and $A$. vaccinii are reported for the first time for Iran mycoflora.

Received 07122014

Accepted 17042015

\section{References}

Aneja J. K., Agarwal, A. A., Agnihorti A. A. 2014. Inter and intra-specific diversity in Alternaria species infecting oilseed Brassicas in India. Journal of Oilseed Brassica, 5 (2): 102-117
Ershad D. 2009. Fungi of Iran. Ministry of Agriculture, Agricultural Research, Education and Extension Organization, 531 p. (in Persian)

Farr D. F., Bills G. F., Chamuris G. P., Rossman A.Y. 1989. Fungi on plants and plant products in the United States. St. Paul, USA, $1252 \mathrm{p}$.

Ghosta Y. 2004. A taxonomic study on the genus Alternaria from Iran: doctoral thesis. Tarbiat Modarres University, Tehran, Iran (in Persian)

Ghosta Y., Ershad D., Zare R., Mohammadi Goltapeh E. 2003. A taxonomic study on Alternaria species in Iran (2). Rostaniha, 4: 87-91 (in English) and 105-121 (in Persian)

Grisan S., Martini M., Musetti R., Osler R. 2011. Development of a molecular approach to describe the diversity of fungal endophytes in either phytoplasma-infected, recovered or healthy grapevines. Bulletin of Insectology, 64: 207-208

Hoog de G. S., Guarro J., Gene J., Figueras M. J. 2000. Atlas of clinical fungi ( $2^{\text {nd }}$ ed.). Utrecht, Reus, $1126 \mathrm{p}$.

Kolte S. J. 2002. Diseases and their management in oilseed crops - new paradigm. Rai M. et al. (eds). Oilseeds and oils - research and development needs. Indian Society of Oilseeds Research, Hyderabad, India, p. 244-253

Kumar D., Maurya N., Bharati Y. K., Kumar A., Kumar K., Srivastava K., Chand G., Kushwaha C., Singh S. K., Mishra R. K., Kumar A. 2014. Alternaria blight of oilseed Brassicas: a comprehensive review. African Journal of Microbiology Research, 8 (30): 2816-2829 http://dx.doi.org/10.5897/AJMR2013.6434

Lawrence D. P., Gannibal P. B., Peever T. L., Pryor B. M. 2013. The sections of Alternaria: formalizing species-groups concepts. Mycologia, 105: 530-546 http://dx.doi.org/10.3852/12-249

Lawrence D. P., Gannibal P. B., Dugan F. M., Pryor B. M. 2014. Characterization of Alternaria isolates from the infectoria species-group and a new taxon from Arrhenatherum, Pseudoalternaria arrhenatheria sp. nov. Mycological Progress, 13: 257-276 http://dx.doi.org/10.1007/s11557-013-0910-x

Michereff S. J., Noronha M. A., Xavier Filha M. S. M., Câmara M. P. S., Reis A. 2012. Survey and prevalence of species causing Alternaria leaf spot on brassica species in Pernambuco. Horticultura Brasileira, 30: 345-348 http://dx.doi.org/10.1590/s0102-05362012000200027

Nourani S. L., Minasian V., Safaei N. 2008. Identification, pathogenicity and distribution of Alternaria spp. of canola in Iran. Iranian Journal of Plant Pathology, 44: 137-154 (in Persian)

Pattanamahakul P., Strange R. N. 1999. Identification and toxicity of Alternaria brassicicola, the causal agent of dark leaf spot disease of Brassica species grown in Thailand. Plant Pathology, 48: 749-755 http://dx.doi.org/10.1046/j.1365-3059.1999.00406.x

Peruch L. A. M., Michereff S. J., Araújo I. B. 2006. Survey of the intensity of Alternaria black spot and black rot on brassica species under organic farming systems in Pernambuco and Santa Catarina states, Brazil. Horticultura Brasileira, 24 (4): 464-469 (in Portuguese) http://dx.doi.org/10.1590/S0102-05362006000400014

Polizzotto R., Andersen B., Martini M., Grisan S., Assante G., Musetti R. 2012. A polyphasic approach for the characterization of endophytic Alternaria strains isolated from grapevines. Journal of Microbiological Methods, 88 (1): 162-171

http://dx.doi.org/10.1016/j.mimet.2011.11.009

Reis A., Boiteux L. S. 2010. Alternaria species infecting Brassicaceae in the Brazilian neotropics: geographical distribution, host range and specificity. Journal of Plant Pathology, 92 (3): 661-668

Rop N. K., Kiprop E. K., Ochuodho J. O. 2009. Alternaria species causing black spot disease of Brassicas in Kenya. $9^{\text {th }}$ African Crop Science Conference Proceedings, p. 635-640 
Simmons E. G. 1986. Alternaria themes and variations (22-26). Mycotaxon, 25: 287-308

Simmons E. G. 1993. Alternaria themes and variations (63-72). Mycotaxon, 48: 91-107

Simmons E. G. 1998. Alternaria themes and variations (224225). Mycotaxon, 68: 417-427

Simmons E. G. 1999. Alternaria themes and variations (226235). Classification of citrus pathogens. Mycotaxon, 70 : 263-323

Simmons E. G. 2000. Alternaria themes and variations (244 286). Species on Solanaceae. Mycotaxon, 75: 1-115

Simmons E. G. 2007. Alternaria: an identification manual. CBS Biodiversity Centre, $757 \mathrm{p}$.
Thomma B. P. H. J. 2003. Alternaria spp.: from general saprophyte to specific parasite. Molecular Plant Pathology, 4: $225-236$ http://dx.doi.org/10.1046/j.1364-3703.2003.00173.x

Wiltshire S. P. 1933. The foundation species of Alternaria and Macrosporium. Transactions of British Mycological Society, $18:$ : $135-160$

http://dx.doi.org/10.1016/S0007-1536(33)80003-9

Wiltshire S. P. 1947. Species of Alternaria on Brassicae. Mycological Papers, 20: 15

Woudenberg J. H. C., Groenewald J. Z., Binder M., Crous P. W. 2013. Alternaria redefined. Studies in Mycology, 75: 171-212 http://dx.doi.org/10.3114/sim0015

ISSN 1392-3196 / e-ISSN 2335-8947

Zemdirbyste-Agriculture, vol. 102, No. 2 (2015), p. 343-350

DOI $10.13080 /$ z-a.2015.102.044

\title{
Alternaria rūšių, aptiktų ant kopūstų, paplitimas Irane
}

\author{
T. Rahimloo, Y. Ghosta \\ Urmijos universitetas, Iranas
}

\section{Santrauka}

Tiriant Alternaria rūšis, kurios sukelia kopūstų juodają dèmètligę, 2012-2013 m. kopūstu laukuose buvo renkami lapai su Alternaria infekcijos simptomais. Ėminiai buvo renkami Irane, Vakarų Azerbaidžano provincijoje. Iš viso buvo surinkti ir taksonomiškai ištirti 135 izoliatai su Alternaria simptomais iš 10 šios provincijos auginimo vietų. Remiantis rastų izoliatų morfologinėmis savybėmis, buvo nustatytos 8 rūšys: A. arbusti, A. brassicicola, A. destruens, A. infectoria, A. perangusta, A. tenuissima, A. turkisafria ir A. vaccinii. Tarp nustatytų rūšių dažniausios ir paplitusios visoje tirtoje teritorijoje buvo $A$. tenuissima (53 izoliatai), A. brassicicola (38 izoliatai) ir A. destruens (29 izoliatai). Rečiausiai aptinkamos rūšys buvo A. arbusti ir A. perangusta (buvo rasta po vieną izoliatą). Tyrimų rezultatai parodè, kad visi tirti izoliatai buvo patogeniški, tačiau tarp pačių izoliatų buvo nustatyti esminiai virulentiškumo skirtumai. Didžiausią virulentiškumą turèjo $A$. brassicicola, mažiausią - A. arbusti ir A. vaccinii izoliatai. Likusios rūšys turèjo vidutinị virulentiškumą. Visos rūšys, išskyrus $A$. brassicicola, kaip kopūstų juodosios dèmètligès sukèlèjos yra aprašytos pirmą kartą. Be to, A. arbusti, A. perangusta ir A. vaccinii yra nustatytos kaip naujos Irane aptinkamos mikrofloros rūšys.

Reikšminiai žodžiai: alternariozè, Brassica oleracea, juodoji dėmètligè, patogenas, taksonomija, virulentiškumas. 